\title{
Tumor necrosis factor- $\alpha$ suppresses the protein fractional synthesis rate of the small intestine stimulated by glutamine in rats
}

\author{
JIHONG ZHOU ${ }^{1 *}$, SHENGXIAN FAN $^{2 *}$, YACHENG CAO ${ }^{3}$, MINGFANG ZHU $^{3}$, \\ YONG HAN ${ }^{3}$, XUEYING CAO ${ }^{1}$ and YOUSHENG $\mathrm{LI}^{2}$ \\ Departments of ${ }^{1}$ Burns and Plastic Surgery, and ${ }^{2}$ General Surgery, Jinling Hospital, Nanjing University School of Medicine; \\ ${ }^{3}$ Institute of Soil Science, Chinese Academy of Sciences, Nanjing, Jiangsu 210002, P.R. China
}

Received April 6, 2014; Accepted October 21, 2014

DOI: $10.3892 /$ etm.2014.2129

\begin{abstract}
The objective of this study was to examine whether and how TNF- $\alpha$ affects glutamine-enhanced protein synthesis and the expression of the amino acid transporter ASCT2 in the small intestine at the mRNA and protein levels. A total of 30 male Sprague-Dawley rats were randomly assigned into three groups, namely the total parenteral nutrition (TPN; control), glutamine-treated (Gln), and glutamine- and tumor necrosis factor- $\alpha(\mathrm{TNF}-\alpha)$-treated (TNF- $\alpha$ ) groups. At $30 \mathrm{~min}$ prior to examination, all rats were mainlined with $\left[\mathrm{L}-{ }^{15} \mathrm{~N}\right]$ leucine. The concentration of TNF- $\alpha$ in plasma and of glutamine in plasma and the small intestine was measured. The fractional synthesis rate (FSR) of protein and the mRNA and protein expression levels of ASCT2 in the small intestine were assessed. The level of TNF- $\alpha$ was highest in the TNF- $\alpha$ group and the glutamine concentration was elevated to a greater extent in the TNF- $\alpha$ group than in the other two groups. However, the FSR of protein in the small intestine was significantly higher in the Gln group compared with that in the TNF- $\alpha$ group. The mRNA and protein expression levels of ASCT2 in the experimental groups were significantly higher that those in the control group, but did not differ significantly between the Gln and TNF- $\alpha$ groups. These results indicate that TNF- $\alpha$ may attenuate glutamine-stimulated protein synthesis in the small intestine in the early stage of sepsis in rats. The mechanism may be that TNF- $\alpha$ inhibits the function of the glutamine transporter in the uptake the glutamine into target cells for protein synthesis. This inhibition may occur at or following protein translation.
\end{abstract}

Correspondence to: Dr Yousheng Li, Department of General Surgery, Jinling Hospital, Nanjing University School of Medicine, 305 East Zhongshan Road, Nanjing, Jiangsu 210002, P.R. China E-mail: liys@medmail.com.cn

*Contributed equally

Key words: ASCT2, fractional synthesis rate, glutamine, glutamine transporter, tumor necrosis factor- $\alpha$

\section{Introduction}

Sepsis is the leading cause of mortality in intensive care units around the world (1). The correct diagnosis and treatment of sepsis is complicated, but must be conducted quickly since a delayed approach increases the risk of mortality. However, following serious injury or illness in animal models of sepsis, the concentrations of glutamine, which is the most abundant free amino acid in the human body under normal conditions, in plasma and tissues fall sharply due to increased requirements by the inflammation-recruited immune cells (2-4). Low plasma glutamine concentration is associated with poor clinical outcome and increased risk of mortality (5). Studies have demonstrated that glutamine can effectively attenuate the rapid progression of sepsis that leads to multiple organ failure and eventually mortality (4,6-11). However, certain studies have disclosed that the effect of glutamine is not ideal in sepsis, especially in the early stage (12-14).

The plasma concentration of glutamine is maintained at a constant level and depends on the relative rate of net amino acid uptake and release by a number of organs. The movement of luminal amino acids across the intestinal brush border membrane is the initial step for transporting exogenous amino acids into systemic circulation. Several transport systems have been implicated in mediating the transport of neutral amino acids, including glutamine, in intestinal epithelial cells. Of these, the main contributor is the $\mathrm{Na}^{+}$-dependent neutral amino acid transport system Ala-, Ser- and Cys- preferring (ASC), which has established a transporter superfamily $(15,16)$. System ASC transporters ASCT1 and ASCT2 are subfamilies that exhibit distinct substrate selectivity. ASCT1 transports Ala, Ser, Thr, Cys and Val, whereas ASCT2 has a broader substrate selectivity. ASCT2 also takes up glutamine with high affinity and accepts a wide range of other amino acids with longer side chains (asparagine, leucine, and isoleucine) (17). In sepsis, particularly in the early stage, the glutamine concentration in the small intestine is significantly decreased and its supplementation causes the arterial plasma concentration of glutamine to increase, yet no effects on the rate of protein synthesis in the small intestine have been observed (18). The mechanism remains unknown. Inflammatory mediators have an essential role in sepsis (19). It is therefore hypothesized that the elevating effect of glutamine on the protein synthesis rate 
may be attenuated by pro-inflammatory cytokines. The aim of this study was to investigate whether tumor necrosis factor- $\alpha$ (TNF- $\alpha$ ), one of the major mediators of sepsis $(19,20)$, inhibits glutamine-induced protein synthesis in the small intestine in a rat model of sepsis. Understanding the mechanism responsible for the lack of effectiveness of glutamine supplementation on protein synthesis may be beneficial to future therapeutic strategies for nutritional support in sepsis.

\section{Materials and methods}

Animals. A total of 30 male Sprague-Dawley (SD) rats, weighing 120-180 g (Shanghai Experimental Animal Center, The Chinese Academy of Sciences, Nanjing, China), were used. For 7 days prior to the experiments, the rats were housed in a temperature-, humidity-, and light-controlled environment on a $12 \mathrm{~h}$ light/12 h dark cycle and were allowed standard rat chow and water ad libitum. The standard rat chow contained (per $100 \mathrm{~g}$ ): $50 \mathrm{~g}$ sucrose, $20 \mathrm{~g}$ casein-vitamin free, $15 \mathrm{~g}$ corn starch, $5 \mathrm{~g}$ powdered cellulose, $5 \mathrm{~g}$ corn oil, $3.5 \mathrm{~g}$ AIN-76A mineral mix, $1 \mathrm{~g}$ AIN-76 vitamin mix, $0.3 \mathrm{~g}$ DL-methionine, $0.2 \mathrm{~g}$ choline bitartrate, and $0.001 \mathrm{~g}$ ethoxyquin. The protocol and animal use were approved by the Animal Research Committee of Nanjing University (Nanjing, China). All procedures were carried out in accordance with the principles of the Guide for the Care and Use of Laboratory Animals (National Institutes of Health publication no. 85-23, revised 1985).

Surgical procedures. Following an overnight fast, the rats were anesthetized with an intraperitoneal injection of ketamine (100 mg/kg body weight). The total parenteral nutrition (TPN) model was constructed, and a rotary transfusion apparatus was used for TPN infusion as described by Eizaguirre et al (21). Immediately following the surgery, all rats were maintained in individual metabolic cages and denied access to food but allowed free access to water to prevent dehydration and maintain hemodynamic homeostasis. Catheterized rats were connected to an infusion pump (Catalogue Celsite ${ }^{\circledR}$; B. Braun Melsungen AG, Tuttlingen, Germany) and saline was infused at an initial rate of $5 \mathrm{ml} / 100 \mathrm{~g}$ body weight per hour.

Experimental design. As the aim of this study was to investigate whether TNF- $\alpha$ inhibits the regulatory effect of glutamine on protein synthesis in the small intestine, it was first tested whether glutamine stimulated protein synthesis in the small intestine and then whether this stimulation was attenuated by TNF- $\alpha$ was examined. Thus, after $24 \mathrm{~h}$ of catheterization, the rats were randomly divided into the following three groups, each containing 10 rats: TPN (control), Gln (treated with glutamine) and TNF- $\alpha$ (treated with glutamine and TNF- $\alpha$ ). The rats in the control group received TPN; the Gln group was given glutamine-enriched TPN, and the TNF- $\alpha$ group was received glutamine-enriched TPN followed by intravenously infused TNF- $\alpha$ for the last $24 \mathrm{~h}$ of the experiment. The parenteral nutrition solution was infused via the infusion pump at a constant rate of $1.5-2 \mathrm{ml} / \mathrm{h}$. The TPN solutions were isonitrogenous and isoenergetic, containing $3.8 \mathrm{~kJ} / \mathrm{ml}$ as a $60 \%$ carbohydrate and $40 \%$ lipid solution, representing $\sim 502 \mathrm{~kJ} / \mathrm{kg} /$ day and $0.75 \mathrm{~g}$ nitrogen $/ \mathrm{kg} /$ day.
The basic formulations included amino acids (Novamin; Fresenius Kabi Pharmaceutical Co., Ltd., Beijing, China), glucose and lipids (Lipovenoes; Fresenius Kabi Pharmaceutical Co., Ltd.). The TPN mixture contained no glutamine, whereas the glutamine-enriched TPN mixture contained $0.15 \mathrm{~g}$ nitrogen per liter and was supplied by Dipeptiven (Glamin ${ }^{\circledR}$, Fresenius Kabi AB, Uppsala, Sweden). The detailed compositions of the two solutions are shown in Table I.

The TPN mixture solutions were freshly prepared aseptically in a laminar flow hood each day. Nutrients were continuously infused for 3 days. Recombinant human TNF- $\alpha$ (PeproTech EC Ltd., London, UK) was diluted in $0.9 \%$ saline and infused intravenously for the final $24 \mathrm{~h}$ at a rate of $5 \mu \mathrm{g} / \mathrm{kg} / \mathrm{h}$, in accordance with a previous study (22). Thirty minutes prior to sampling, all rats were injected with [L- ${ }^{15} \mathrm{~N}$ leucine $(1 \mathrm{mmol} / \mathrm{kg}$; Cambridge Isotope Laboratories, Inc., Andover, MA, USA).

Sample analysis. The rats were sacrificed by decapitation after $72 \mathrm{~h}$ of TPN. Blood was collected into lithium heparin tubes and centrifuged at $3,000 \mathrm{xg}$ at $4^{\circ} \mathrm{C}$ for $10 \mathrm{~min}$. The plasma was decanted and stored at $-70^{\circ} \mathrm{C}$ until analysis. The small intestine was rapidly dissected, and the dissected small intestine was plunged into an ice-water slurry $\left(0^{\circ} \mathrm{C}-4^{\circ} \mathrm{C}\right)$, at which time it was assumed that all metabolic processes including protein synthesis had ceased or were negligible. Samples of the small intestine were then weighed, flash-frozen in liquid nitrogen, and subsequently stored at $-70^{\circ} \mathrm{C}$ until analysis.

TNF- $\alpha$ measurement. The plasma level of TNF- $\alpha$ was analyzed with a sandwich enzyme-linked immunosorbent assay from PeproTech EC Ltd. and performed according to the manufacturer's instructions.

Glutamine concentration in plasma and small intestine. The glutamine concentration in plasma and tissue from the small intestine, extracted from a homogenate, were measured using high-performance liquid chromatography, as described previously (23).

Protein synthesis rate. Rates of protein synthesis were measured based on a 'flooding dose' technique described previously by Garlick et al (24). The small intestine was divided into two sections of similar weight, prior to freezing, each section weighing 50 mg. Subsequently, protein analysis was performed on one section only, with the other section being used for the glutamine assay.

The sample of intestine was homogenized and then precipitated in $10 \mathrm{ml} 0.2 \mathrm{~mol} / 1$ protein perchloric acid. Following

$$
F S R=\frac{E_{B(t)}-E_{B(0)}}{\int_{0}^{t} E_{F(t)} d t}
$$

centrifugation $\left(2,000 \mathrm{x} \mathrm{g}, 4^{\circ} \mathrm{C}, 15 \mathrm{~min}\right)$, the supernatant was decanted for subsequent neutralization and measurement of the enrichment of free amino acids $\left(\mathrm{E}_{\mathrm{F}}\right.$; see below). The protein pellets were washed twice in $10-12 \mathrm{ml} 0.2 \mathrm{~mol} / 1$ perchloric acid followed by centrifugation $\left(2,000 \mathrm{x} \mathrm{g}, 4^{\circ} \mathrm{C}, 15 \mathrm{~min}\right)$ to remove contaminating free leucine. The pellets were then digested in 
Table I. Compositions of amino acid solutions.

\begin{tabular}{lcc}
\hline Amino acids & TPN $(\mathrm{g} / \mathrm{l})$ & $\mathrm{Gln}(\mathrm{g} / \mathrm{l})$ \\
\hline Alanine & 12.2 & 9.8 \\
Arginine & 8.4 & 6.7 \\
Aspartic acid & 2.5 & 2.0 \\
Cystine & 0.2 & 0.2 \\
Glutamic acid & 4.2 & 3.3 \\
Glycine & 5.9 & 4.7 \\
Histidine & 5.0 & 4.0 \\
Isoleucine & 4.2 & 3.4 \\
Leucine & 5.9 & 4.7 \\
Lysine & 9.5 & 7.6 \\
Methionine & 4.2 & 3.4 \\
Phenylalanine & 5.9 & 4.7 \\
Proline & 5.0 & 4.0 \\
Serine & 3.4 & 2.7 \\
Threonine & 4.2 & 3.4 \\
Tryptophan & 1.4 & 1.1 \\
Tyrosine & 0.2 & 0.2 \\
Valine & 5.5 & 4.4 \\
L-glutamine & - & 15.9 \\
Total amino acids & 85.0 & 88.0 \\
Total nitrogen & 14.0 & 14.0 \\
\hline
\end{tabular}

TPN, total parenteral nutrition. Gln is glutamine-enriched TPN. Composition of TPN: 11 TPN provides $3,766 \mathrm{~kJ}$ and $7.5 \mathrm{~g}$ of nitrogen $(\mathrm{kJ} /$ nitrogen $=502)$.

$10 \mathrm{ml} 0.3 \mathrm{~mol} / 1 \mathrm{NaOH}$ at $37^{\circ} \mathrm{C}$ for $1 \mathrm{~h}$, re-precipitating with $4 \mathrm{~mol} / \mathrm{l}$ perchloric acid to further disrupt any cellular compartments that still contained free leucine. The pellets were then washed eight times with $0.2 \mathrm{~mol} / 1$ perchloric acid and hydrolyzed in $3.0 \mathrm{ml} 6 \mathrm{~mol} / 1 \mathrm{HCl}$ for $24 \mathrm{~h}$ at $105^{\circ} \mathrm{C}$. The hydrolysates were vacuum-dried. Dried residues were then suspended in $3.0 \mathrm{ml}$ sodium citrate buffer ( $\mathrm{pH} 6.3 ; 1.5 \mathrm{~mol} / \mathrm{l})$, and samples were stored at $-4^{\circ} \mathrm{C}$ until processed for measurement of the enrichment of protein-bound leucine $\left(\mathrm{E}_{\mathrm{B}}\right)(25)$.

The fractional synthesis rate (FSR) of protein, defined as the percentage of tissue protein renewed by synthesis each day, was calculated by the following equation (26):

$E_{B}$ is the enrichment of ${ }^{15} \mathrm{~N}$ of protein-bound leucine, $E_{F}$ is the enrichment of tissue-free leucine, and $t$ is the period from injection of the isotope to the immersion of the tissue into iced water. The enrichment of ${ }^{15} \mathrm{~N}$ of protein-bound and tissue-free leucine was detected by mass spectrometry (Finnigan MAT; Thermo Fisher Scientific, San Jose, CA, USA).

ASCT2 $m R N A$ determination by reverse transcription quantitative polymerase chain reaction $(R T-q) P C R$. Total RNA was extracted from each $0.5 \mathrm{ml}$ purified sample using TRIzol (Invitrogen Life Technologies, Carlsbad, CA, USA), and stored in $1 \mathrm{ml}$ dehydrated alcohol at $-80^{\circ} \mathrm{C}$. The specific PCR primers and fluorescently-labeled probes that were used are listed in Table II. The total RNA from each sample was reverse-tran-
Table II. Sequences of qPCR primers and probes.

\begin{tabular}{ll}
$\begin{array}{l}\text { Primer/ } \\
\text { probe }\end{array}$ & \multicolumn{1}{c}{ Sequence } \\
\hline Primer & F: 5'-GCAGCCTAGACCTGGGATCAC-3' \\
& R: 5'-GCGGTCTTTGATTCCCTGAA-3' \\
Probe & Fam - ATCTTGGGTTCCCGGAGCCAG \\
& ACAT - TAMRA
\end{tabular}

qPCR, quantitative polymerase chain reaction; F, forward; R, reverse; Fam, carboxyfluorescein; TAMRA, tetramethylrhodamine.

scribed into first-strand cDNA in a $20-\mu 1$ reaction system (RT buffer $10 \mu \mathrm{l}, 100 \mathrm{pmol} / \mu \mathrm{l}$ primers $1 \mu \mathrm{l}$, RT-mix $1 \mu \mathrm{l}$, RNA $5 \mu \mathrm{l}$ and deionized DEPC water $13 \mu \mathrm{l}$ ) under the following conditions: denaturation at $25^{\circ} \mathrm{C}$ for $10 \mathrm{~min}$, annealing at $40^{\circ} \mathrm{C}$ for $60 \mathrm{~min}$, and synthesis at $70^{\circ} \mathrm{C}$ for $10 \mathrm{~min}$, for 40 cycles. qPCR was performed using a sequence detector system (FTC-2000; Funglyn Biotech Corporation, Toronto, Canada) with specific individual primer pairs and fluorescently-labeled probe in $50 \mu 1$ reaction mixture (PCR buffer $25 \mu 1,25 \mathrm{pmol} / \mu 1$ primers $0.6 \mu 1 \times 2$, probe $0.4 \mu 1$, cDNA $1 \mu 1$, deionized DEPC water $22.4 \mu \mathrm{l})$ using the following conditions: $94^{\circ} \mathrm{C}$ for $4 \mathrm{~min}$, annealing at $94^{\circ} \mathrm{C}$ for $30 \mathrm{sec}$, and synthesis at $60^{\circ} \mathrm{C}$ for $30 \mathrm{sec}$, for 40 cycles. The progress of the PCR amplification was monitored in real-time by fluorescent measurement during each cycle, and the relative concentration of the target gene was quantified with GAPDH. The analysis of PCR results and calculation were performed using Rotor-Gene software (version 6; Corbett Robotics Inc., Qiagen, San Francisco, CA, USA) and the control levels were set at 1 . All procedures were performed at least three times.

ASCT2 protein determination by western blotting. Protein samples $(5 \mu \mathrm{g})$ were electrophoretically separated on SDS polyacrylamide gel and transferred to a polyvinylidene difluoride membrane that was blocked with blocking solution $(5 \% \mathrm{w} / \mathrm{v}$ skimmed milk) at room temperature for $2 \mathrm{~h}$. The membrane was then incubated overnight with the goat anti-mouse polyclonal antibody to ASCT2 (dilution 1:500; Santa Cruz Biotechnology, Inc., Santa Cruz, CA, USA) diluted in Tris-buffered saline with $0.1 \%$ Tween 20 (TBST). Then, the membrane was incubated with donkey anti-sheep IgG-HRP antibody (dilution 1:10,000; Santa Cruz Biotechnology, Inc.) at room temperature for $1 \mathrm{~h}$ and was treated with the enhanced chemiluminescence western blot (ECL-WB) assay (Perkin Elmer, Inc., Waltham, MA, USA). Semiquantitative assessment of bands was performed densitometrically using Quantity One software (Bio-Rad, Hercules, CA, USA). The detection and assessment procedure were repeated at least three times.

Statistical analysis. Data are presented as the mean \pm standard error of the mean. One way analysis of variance followed by the Student-Newman-Keuls test was used to assess the means among multi-groups while the Dunnett's T3 test was used to 
Table III. Plasma TNF- $\alpha$ level, plasma and small intestine glutamine levels, and the fractional synthesis rate of protein in the small intestine.

\begin{tabular}{lccc}
\hline Variable & Con $(\mathrm{n}=10)$ & Gln $(\mathrm{n}=10)$ & TNF- $\alpha(\mathrm{n}=10)$ \\
\hline Plasma & & & \\
TNF- $\alpha(\mathrm{pg} / \mathrm{ml})$ & $7.903 \pm 2.119$ & $5.442 \pm 1.926$ & $1673.767 \pm 108.774^{\mathrm{b}}$ \\
Gln $(\mu \mathrm{mol} / \mathrm{l})$ & $376.766 \pm 33.045$ & $403.516 \pm 26.759^{\mathrm{a}}$ & $440.816 \pm 44.434^{\mathrm{b}}$ \\
Small intestine & & & \\
Gln $(\mu$ mol/l $)$ & $0.165 \pm 0.010$ & $0.203 \pm 0.008^{\mathrm{a}}$ & $0.428 \pm 0.012^{\mathrm{b}}$ \\
FSR $(\%$ per day $)$ & $4.005 \pm 0.020$ & $4.669 \pm 0.040^{\mathrm{a}}$ & $4.463 \pm 0.040^{\mathrm{c}}$ \\
\hline
\end{tabular}

The levels of tumor necrosis factor- $\alpha(\mathrm{TNF}-\alpha)$ and glutamine (Gln) were determined by an enzyme-linked immunosorbent assay and high-performance liquid chromatography, respectively. The fractional synthesis rate (FSR) of protein was determined using a stable isotope, as described in Materials and methods. Data are expressed as mean \pm SEM. Con, total parenteral nutrition (TPN) group ( $\mathrm{n}=10)$, supplied with TPN; Gln, glutamine-treated group $(n=10)$, supplied with glutamine-enriched TPN; TNF- $\alpha$, TNF- $\alpha$ and glutamine group ( $n=10)$, supplied with glutamine-enriched TPN and treated with TNF- $\alpha$. ${ }^{\mathrm{a}} \mathrm{P}<0.01$, vs. the TPN group, ${ }^{\mathrm{b}} \mathrm{P}<0.01$, vs. the Gln group and ${ }^{\mathrm{c}} \mathrm{P}<0.05$ vs. the Gln group, each as determined by analysis of variance followed by the Student-Newman-Keuls test.

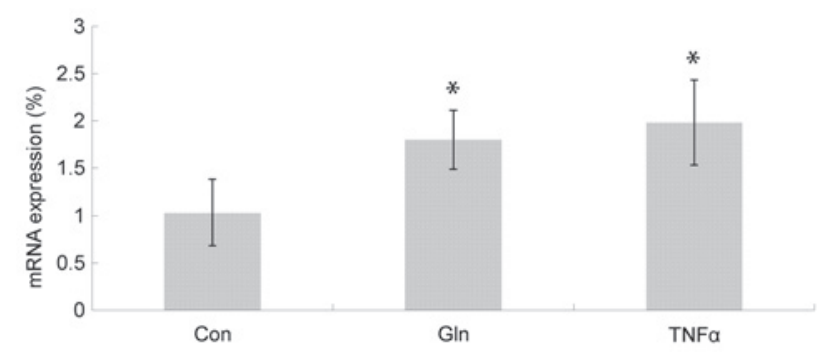

Figure 1. mRNA expression level of ASCT2 in the small intestine. The mRNA expression levels of ASCT2 in the experimental groups were significantly higher than that in the control (Con) group, and the difference between the Gln and TNF- $\alpha$ groups was not significant. All data are presented as the mean \pm SEM. Con, total parenteral nutrition (TPN) group $(\mathrm{n}=10)$, supplied with TPN; Gln, glutamine-treated group $(\mathrm{n}=10)$, supplied with glutamine-enriched TPN; TNF- $\alpha$, TNF- $\alpha$ and glutamine group $(n=10)$, supplied with glutamine-enriched TPN and treated with TNF- $\alpha .{ }^{*} \mathrm{P}<0.01$, compared with the control group.

assess pairwise multiple comparisons. Statistical Package for Social Sciences (SPSS, Inc., Chicago, IL, USA) version 11.0 was used for data analysis. Statistical significance was accepted at the $\mathrm{P}<0.01$ level.

\section{Results}

Plasma TNF- $\alpha$ level. The plasma levels of TNF- $\alpha$ in the three groups are presented in Table III. Following the continuous infusion of TNF- $\alpha$ for $24 \mathrm{~h}$, the TNF- $\alpha$ levels in the plasma were significantly elevated in the TNF- $\alpha$ group and were significantly higher than those in the other two groups $(\mathrm{P}<0.01)$. No statistically significant difference in TNF- $\alpha$ level was identified between the TPN (control) and Gln groups. Thus, the infusion protocol elevated the circulating TNF- $\alpha$ concentration to a high level.

Plasma glutamine level. The plasma levels of glutamine are also presented in Table III. The plasma glutamine level was lowest in the TPN group, and increased markedly following

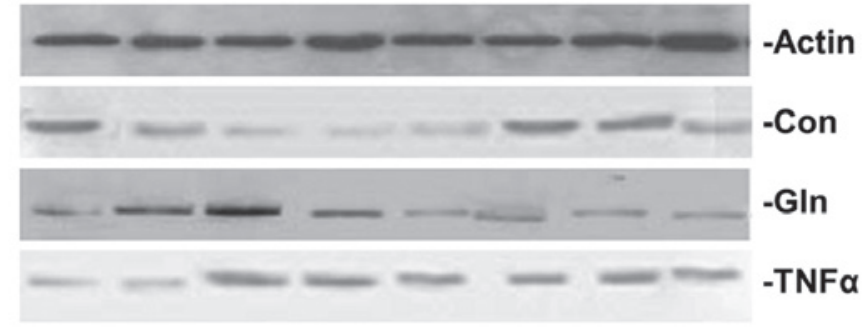

Figure 2. Protein expression of ASCT2 in the small intestine. Con, total parenteral nutrition (TPN) group, supplied with TPN; Gln, glutamine-treated group, supplied with glutamine-enriched TPN; TNF- $\alpha$, TNF- $\alpha$ and glutamine group $(n=10)$, supplied with glutamine-enriched TPN and treated with TNF- $\alpha$.

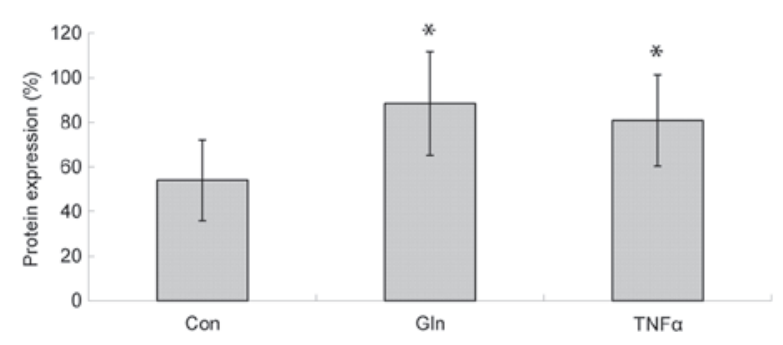

Figure 3. Protein expression of ASCT2 in the small intestine. The protein expression levels of ASCT2 in the experimental groups were significantly higher than that in the control (Con) group, and the level in the Gln group was slightly higher than that in the TNF- $\alpha$ group; however, the difference between the Gln and TNF- $\alpha$ groups was not significant. All data are presented as mean \pm SEM. Con, total parenteral nutrition $(T P N)$ group $(n=10)$, supplied with TPN; Gln, glutamine-treated group $(n=10)$, supplied with glutamine-enriched TPN; TNF- $\alpha$, TNF- $\alpha$ and glutamine group $(n=10)$, supplied with glutamine-enriched TPN and treated with TNF- $\alpha$. ${ }^{*} \mathrm{P}<0.01$ compared with the Con group.

treatment with glutamine and TNF- $\alpha$, and was the highest in the TNF- $\alpha$ group. There was a significant difference among the three groups $(\mathrm{P}<0.01)$. Supplementation with a combination of glutamine and TNF- $\alpha$ significantly increased the free glutamine concentration in plasma. 
Small intestine glutamine level. The concentration of glutamine in the small intestine is shown in Table III. An increase in glutamine concentration was observed in the small intestine after $24 \mathrm{~h}$ of intravenous infusion with TNF- $\alpha$ compared with that in the TPN group $(\mathrm{P}<0.01)$. The maximal increase of glutamine concentration was observed in the group treated with a combination of TNF- $\alpha$ and $\mathrm{Gln}(\mathrm{P}<0.01$ compared with the Gln group). Thus, the combination of TNF- $\alpha$ and glutamine increased the free glutamine level in the small intestine.

Small intestine protein FSR. As shown in Table III, there was a significant increase in the FSR of protein in the small intestine in the Gln group. The difference among the three groups was significant $(\mathrm{P}<0.01)$. The protein FSR was higher in the Gln group than in the TPN group, and it may be concluded that glutamine is able to increase protein synthesis in the small intestine. However, the effect of glutamine on protein synthesis was not observed in TNF- $\alpha$ group. Following treatment with TNF- $\alpha$, the protein FSR of the small intestine in the TNF- $\alpha$ group was markedly decreased compared with that in the Gln group. Thus, TNF- $\alpha$ attenuated the stimulative effect of glutamine on protein synthesis in the small intestine of rats.

$m R N A$ expression level of ASCT2. As shown in Fig. 1, the mRNA expression levels of ASCT2 in the experimental groups were significantly higher than that in the TPN group $(\mathrm{P}<0.01)$. Although the mRNA expression level of ASCT2 was higher in the TNF- $\alpha$ group than that in Gln group, the difference between these two groups was not significant.

Effect of TNF- $\alpha$ on the protein expression level of ASCT2. The protein expression of ASCT2 was identified in all groups (Fig. 2). Among the three groups, the protein expression levels of ASCT2 in the Gln and TNF- $\alpha$ groups were significantly higher than those in the control (Con) group $(\mathrm{P}<0.01)$, and were slightly higher in the Gln group than in the TNF- $\alpha$ group. However, the difference between the Gln and TNF- $\alpha$ groups was not statistically significant (Fig. 3).

\section{Discussion}

Sepsis has become a major worldwide health problem due to the continual increase of its incidence, as well as its high mortality rate (27-29). Therefore, the prevention and treatment of sepsis has become an important focus in medical research. Previous studies have disclosed that glutamine supplementation in sepsis is not necessarily effective in increasing protein synthesis in the skeletal muscle of rats $(30,31,32)$. Other studies have shown that in endotoxin-treated rats or rats with septic abscesses, parenteral supplementation with glutamine could only increase muscle glutamine levels, not muscle protein synthesis $(32,33)$.

In the present study, the changes in rats induced by an intravenous injection of TNF- $\alpha$ were investigated. The results showed the plasma TNF- $\alpha$ rose to a high level and was similar to that observed in sepsis (34). The present study showed that a combination of TNF- $\alpha$ and glutamine increased the free glutamine concentration, and TNF- $\alpha$ increased the free glutamine concentration in plasma and the small intestine significantly. Previous simulation experiments have demonstrated that in the early stage of sepsis, the concentration of free glutamine is increased, not reduced (35). Similar to another study (36), the present study showed that glutamine could indeed promote protein synthesis, but that the function of glutamine could be inhibited by TNF- $\alpha$.

Therefore, the high concentration of extracellular glutamine fails to be utilized well under infection conditions. As an amino acid, the process of transmembrane transport depends on the normal structure and function of glutamine transporters. The first glutamine transporter was isolated more than 40 years ago, and large numbers of transporters have now been isolated (37-40). ASCT2 is a transporter of the Ala-, Serand Cys-preferring (ASC) system. It has a high affinity for glutamine transportation, and is distributed widely in all kinds of cells (41-45). There have been numerous studies on ASCT2 with gradually advancing methods $(17,46)$. The failure of a high concentration of extracellular glutamine to exert effects may occur as a result of the limitation of transporter function.

The present study also demonstrated that TNF- $\alpha$ had a modest promoting effect on the expression of ASCT2 mRNA, which indicates the suppressive effect of TNF- $\alpha$ did not occur at the transcription level. There are two major methods by which protein function is regulated: one is the alteration of expression while the other is conformational change at the functional site. The present study revealed that although TNF- $\alpha$ suppressed the expression of the ASCT2 glutamine transporter protein, the magnitude of the reduction was not significant, which indicated that the suppression of transporter function may be accompanied by structural changes to the transporter. However, the molecular mechanism of the effect of TNF- $\alpha$ on glutamine utilization remains unclear.

In conclusion, the present study suggests that TNF- $\alpha$ attenuates the glutamine-induced stimulation of protein synthesis in the small intestine. The mechanism may be that TNF- $\alpha$ inhibited the function of glutamine transporters in the uptake the glutamine into target cells for protein synthesis. This inhibition may occur at or after protein translation. However, additional studies on whether TNF- $\alpha$ affects the structure of glutamine transporters and on how TNF- $\alpha$ affects the structure of glutamine transporters are required.

\section{Acknowledgements}

This study was supported by grants from the National Natural Science Foundation of China (no. 81270945 and no. 30672060).

\section{References}

1. Bello G, Di Muzio F, Maviglia R and Antonelli M: New membranes for extracorporeal blood purification in septic conditions. Minerva Anestesiol 78: 1265-1281, 2012.

2. Newsholme P: Why is L-glutamine metabolism important to cells of the immune system in health, postinjury, surgery or infection? J Nutr 131 (9 Suppl): 2515S-2522S, 2001.

3. Rodas PC, Rooyackers O, Hebert C, Norberg A and Wernerman J: Glutamine and glutathione at ICU admission in relation to outcome. Clin Sci (Lond) 122: 591-597, 2012.

4. Lin Z, Cai F, Lin N, Ye J, Zheng Q and Ding G: Effects of glutamine on oxidative stress and nuclear factor- $\kappa \mathrm{B}$ expression in the livers of rats with nonalcoholic fatty liver disease. Exp Ther Med 7: 365-370, 2014

5. Boelens PG, Nijveldt RJ, Houdijk AP, Meijer $S$ and van Leeuwen PA: Glutamine alimentation in catabolic state. J Nutr 131: 2569S-2577S; discussion 2590S, 2001. 
6. D'Souza R and Powell-Tuck J: Glutamine supplements in the critically ill. J R Soc Med 97: 425-427, 2004.

7. Goeters C, Wenn A, Mertes N, Wempe C, Van Aken H, Stehle P and Bone HG: Parenteral L-alanyl-L-glutamine improves 6 -month outcome in critically ill patients. Crit Care Med 30: 2032-2037, 2002.

8. García-de-Lorenzo A, Zarazaga A, García-Luna PP, et al: Clinical evidence for enteral nutritional support with glutamine: a systematic review. Nutrition 19: 805-811, 2003.

9. Cohen J and Chin WDN: Nutrition and sepsis. World Rev Nutr Diet 105: 116-125, 2013.

10. Kim M and Wischmeyer PE: Glutamine. World Rev Nutr Diet 105: 90-96, 2013.

11. Bakalar B, Duska F, Pachl J, Fric M, Otahal M, Pazout J and Andel M: Parenterally administered dipeptide alanyl-glutamine prevents worsening of insulin sensitivity in multiple-trauma patients. Crit Care Med 34: 381-386, 2006.

12. Forbes A: Parenteral nutrition. Curr Opin Gastroenterol 23 183-186, 2007.

13. Gore DC and Wolfe RR: Glutamine supplementation fails to affect muscle protein kinetics in critically ill patients. JPEN J Parenter Enteral Nutr 26: 342-350, 2002.

14. Gottschalk A, Wempe C and Goeters C: Glutamine in the ICU: who needs supply? Clin Nutr 32: 668-669, 2013.

15. Devés R and Boyd CA: Transporters for cationic amino acids in animal cells: discovery, structure, and function. Physiol Rev 78: 487-545, 1998

16. Palacín M, Estévez R, Bertran J and Zorzano A: Molecular biology of mammalian plasma membrane amino acid transporters. Physiol Rev 78: 969-1054, 1998

17. Kanai Y and Hediger M: The glutamate/neutral amino acid transporter family SLC1: molecular, physiological, and pharmacological aspects. Pflugers Arch 447: 469-479, 2004

18. Wang H, Pan JK, Sun M, Zhou Z and Gao H: Effects of glutamine on alpha-sarcomeric actin and its mRNA expression of myocardium in rats with endotoxemia. Zhonghua Er Ke Za Zhi 43: 925-929, 2005 (In Chinese).

19. Wischmeyer PE, Riehm J, Singleton KD, Ren H, Musch MW, Kahana M and Chang EB: Glutamine attenuates tumor necrosis factor-alpha release and enhances heat shock protein 72 in human peripheral blood mononuclear cells. Nutrition 19: 1-6, 2003.

20. Scheibe R, Schade M, Grundling M, et al: Glutamine and alanyl-glutamine dipeptide reduce mesenteric plasma extravasation, leukocyte adhesion and tumor necrosis factor-alpha (TNF-alpha) release during experimental endotoxemia. J Physiol Pharmacol 60 (Suppl 8): 19-24, 2009.

21. Eizaguirre I, Aldazabal P, Barrena MJ, Garcia-Arenzana JM, Ariz C, Candelas S and Tovar JA: Effect of growth hormone on bacterial translocation in experimental short-bowel syndrome. Pediatr Surg Int 15: 160-163, 1999.

22. Lang CH, Frost RA, Nairn AC, MacLean DA and Vary TC: TNF-alpha impairs heart and skeletal muscle protein synthesis by altering translation initiation. Am J Physiol 282: E336-E347, 2002.

23. Liu F, Li J, Chen Y and Li Y: Plasma glutamine level monitored with high performance liquid chromatography for patient infusing glutamine after small bowel transplantation. Se Pu 15: 445-447, 1997 (In Chinese).

24. Garlick PJ, Wernerman J, McNurlan MA, et al: Measurement of the rate of protein synthesis in muscle of postabsorptive young men by injection of a "flooding dose" of $\left[1-{ }^{13} \mathrm{C}\right]$ leucine. Clin Sci (Lond) 77: 329-336, 1989.

25. O'Leary MJ, Ferguson CN, Rennie MJ, Hinds CJ, Coakley JH and Preedy VR: Sequential changes in vivo muscle and liver protein synthesis and plasma and tissue glutamine levels in sepsis in the rat. Clin Sci (Lond) 101: 295-304, 2001.

26. Zilversmit DB: The design and analysis of isotope experiments. Am J Med 29: 832-848, 1960.
27. Hotchkiss RS and Karl IE: The pathophysiology and treatment of sepsis. N Engl J Med 348: 138-150, 2003.

28. Martin GS, Mannino DM, Eaton S and Moss M: The epidemiology of sepsis in the United States from 1979 through 2000 N Engl J Med 348: 1546-1554, 2003.

29. Tjader I,Berg A and Wernerman J: Exogenous glutamine-compensating a shortage? Crit Care Med 35 (9 Suppl): S553-S556, 2007

30. O'Leary MJ, Ferguson CN, Rennie M, Hinds CJ, Coakley JH and Preedy VR: Effect of growth hormone on muscle and liver protein synthesis in septic rats receiving glutamine-enriched parenteral nutrition. Crit Care Med 30: 1099-1105, 2002.

31. Safránek R, Holecek M, Sispera L and Muthný T: Aspects of protein and amino acid metabolism in a model of severe glutamine deficiency in sepsis. Ann Nutr Metab 50: 361-367, 2006.

32. Zhou J, Li Y, Liu F, Cao Y and Li J: Tumor necrosis factor $\alpha$ attenuates glutamine-enhanced skeletal muscle protein synthesis in rats. Nutr Res 27: 772-777, 2007.

33. Jepson MM and Millward DJ: Impact of glutamine infusions on muscle protein synthesis in fasted and endotoxin treated rats. Clin Nutr 10: 43-46, 1991

34. Fan J, Char D, Bagby GJ, Gelato MC and Lang CH: Regulation of insulin-like growth factor-I (IGF-I) and IGF-binding proteins by tumor necrosis factor. Am J Physiol 269: R1204-R1212, 1995.

35. Wang W, Li Y, Zhang W, Zhang F and Li J: Changes of plasma glutamine concentration and hepatocyte membrane system $\mathrm{N}$ transporters expression in early endotoxemia. J Surg Res 166: 290-297, 2011.

36. Curi R, Lagranha CJ, Doi SQ, et al: Molecular mechanisms of glutamine action. J Cell Physiol 204: 392-401, 2005.

37. Mackenzie B and Erickson JD: Sodium-coupled neutral amino acid (System N/A) transporters of the SLC38 gene family. Pflugers Arch 447: 784-795, 2004

38. Van den Eynden J, Notelaers K, Brône B, et al: Glycine enhances microglial intracellular calcium signaling. A role for sodium-coupled neutral amino acid transporters. Pflugers Arch 461: 481-491, 2011.

39. Bodoy S, Martin L, Zorzano A, Palacín M, Estévez R and Bertran J: Identification of LAT4, a novel amino acid transporter with system L activity. J Biol Chem 280: 12002-12011, 2005.

40. Verrey F, Closs EI, Wagner CA, Palacin M, Endou H and Kanai Y: CATs and HATs: the SLC7 family of amino acid transporters. Pflugers Arch 447: 532-542, 2004

41. Yoshikawa R, Yasuda J, Kobayashi T and Miyazawa T: Canine ASCT1 and ASCT2 are functional receptors for RD-114 virus in dogs. J Gen Virol 93: 603-607, 2012.

42. Indiveri C: Studying amino acid transport using liposomes. Methods Mol Biol 606: 55-68, 2010.

43. Gliddon CM, Shao Z, LeMaistre JL and Anderson CM: Cellular distribution of the neutral amino acid transporter subtype ASCT2 in mouse brain. J Neurochem 108: 372-383, 2009.

44. Avissar NE, Sax HC and Toia L: In human entrocytes, GLN transport and ASCT2 surface expression induced by short-term EGF are MAPK, PI3K, and Rho-dependent. Dig Dis Sci 53: 2113-2125, 2008

45. Fuchs BC, Finger RE, Onan MC and Bode BP: ASCT2 silencing regulates mammalian target-of-rapamycin growth and survival signaling in human hepatoma cells. Am J Physiol Cell Physiol 293: C55-C63, 2007.

46. Avissar NE, Ziegler TR and Toia L: ATB0/ASCT2 expression in residual rabbit bowel is decreased after massive enterectomy and is restored by growth. hormone treatment. J Nutr 134: 2173-2177, 2004.

47. Kanai $Y$ and Hediger MA: The glutamate/neutral amino acid transporter family SLC1: molecular, physiological and pharmacological aspects. Pflugers Arch 447: 469-479, 2004. 